\title{
PENGARUH LAYANAN INFORMASI DENGAN MEDIA TEKNOLOGI INFORMASI DAN KOMUNIKASI (TIK) TERHADAP PEMAHAMAN SISWA TENTANG DAMPAK PERILAKU SEKS BEBASPADA SISWA KELAS VIII 4 DI SMP N 3 KOTA BENGKULU
}

\author{
Sinlin, I Wayan Dharmayana, Afifatus Sholihah \\ Prodi Bimbingan dan Konseling Fakultas Keguruan dan Ilmu Pendidikan \\ Universitas Bengkulu, \\ sinlinsaja@gmail.com, iwayand386@gmail.com, afifatus@unib.ac.id
}

\begin{abstract}
ABSTRAK
Penelitian ini bertujuan untuk mendeskripsikan pengaruh layanan informasi dengan media teknologi informasi dan komunikasi (TIK) terhadap pemahaman siswa tentang dampak perilaku seks bebas pada siswa kelas VIII 4 di SMP N 3 Kota Bengkulu. Peneliti ini menggunakan metode kuantitatif. Jenis penelitia ini menggunakan teknik purposive sampling dengan Desain penelitian one group pretest dan posttest design, dengan Sampel penelitian berjumlah 31 orang dari kelas VIII 4 tahun ajaran 2019/2020 yang memiliki pemahaman tentang dampak perilaku seks bebas dalam kategori sedang. Teknik pengumpulan data dalam penelitian ini menggunakan angket pemahaman tentang dampak perilaku seks bebas. Berdasarkan hasil penelitian, diketahui terdapat peningkatan pemahaman siswa tentang dampak perilaku seks bebas dengan layanan informasi. Hasil analisis data pretest pada siswa setelah diberikan layanan informasi dengan menggunakan uji t paired sampel test. Dengan nilai $\mathrm{t}=-23,826(\mathrm{p}<0,05)$. Maka dapat disimpulkan bahwa ada pengaruh antara layanan informasi dengan media teknologi informasi dan komunikasi (TIK) terhadap pemahaman siswa tentang dampak perilaku seks bebas di SMP N 3 Kota Bengkulu.
\end{abstract}

Kata kunci : layanan informasi, pemahaman, bahaya seks bebas

\section{THE EFFECT OF INFORMATION SERVICE WITH INFORMATION AND COMMUNICATION TECHNOLOGY MEDIA ON STUDENTS 'UNDERSTANDING ON THE IMPACT OF FREE SEX BEHAVIORIN CLASS VIII 4 STUDENTS IN SMP N 3BENGKULU CITY}

\begin{abstract}
This study aims to describe the effect of information services with information and communication technology (ICT) media on students' understanding of the impact of free sex behavior on grade VIII 4 students at SMP N 3 Bengkulu City. This research uses quantitative methods. This type of research uses a purposive sampling technique with one group pretest and posttest design research design, with a sample of 31 people from class VIII 4 in 2019/2020 academic year who have an understanding of the impact of free sex in the medium category. Data collection techniques in this study used a questionnaire of understanding about the effects of free sex. Based on the results of the study, it was found that there was an increase in students' understanding of the impact of free sex behavior with information services. The results of the analysis of pretest data on students after being provided with information services using paired sample $t$ test. With a value of $t=-23.826(p<0.05)$. Then it can be concluded that there is an influence between information services and information and communication technology (ICT) media on students' understanding of the effects of free sex in SMP N 3 Bengkulu City.
\end{abstract}

Keywords : information services, understanding, dangers of free sex 


\section{Pendahuluan}

Masa remaja adalah masa yang penuh gejolak, masa yang penuh dengan berbagai pengenalan dan petualangan akan hal-hal yang baru sebagai bekal untuk mengisi kehidupan mereka kelak. Masa remaja merupakan masa transisi dengan perubahan fisik begitu drastis, perubahan psikologi yang labil dan penyesuaian lingkungan sosial baru (Willis, 2005:53). Secara tidak langsung, remaja saat ini bnayak sekali mengadopsi kebudayaan luar sebagai trend penyesuaian sosial agar terlihat modern. Namun, tidak semua budaya luar yang diikuti ini baik dan sesuai dengan norma yang berlaku di masyarakat Indonesia.

Salah satu contoh kebudayaan asing yang tidak cocok dengan kebudayaan negara kita yaitu seks bebas. Pada saat ini kebebasan bergaul sudah sampai pada tingkat yang mengkhawatirkan. Remaja dengan bebas dapat bergaul dengan lawan jenis. Tidak jarang di tempat-tempat umum, para remaja sering berangkulan mesra tanpa memperdulikan yang berada disekitarnya, bahkan berhubungan seks sudah dianggap sebagai hal yang biasa di kalangan remaja.

Dariyo (2004) mengatakan pergaulan bebas yang tak terkendali secara normatif dan etika-moral antar remaja yang berlainan jenis, akan berakibat adanya hubungan seksual di luar nikah (pergaulan bebas/ seks pranikah). Free sex atau seks bebas menjadi hal yang sangat biasa bagi kalangan remaja saat ini, tanpa merasa malu mereka meminta pasangannya untuk melakukan hal itu, hal yang sebenarnya dianggap tabu oleh masyarakat sekitar. Bukan hanya wanita dewasa (> 20 tahun) saja yang melakukannya, namun sekarang kalangan remaja SMP-SMA sudah melakukannya walaupun hanya satu kali.

Pengertian perilaku seks bebas adalah tingkah laku yang didorong oleh hasrat seksual baik dengan lawan jenis yang dilakukan oleh sebagian remaja tanpa ada ikatan resmi baik secara hukum maupun agama yang melanggar norma-norma dan cenderung untuk mencari kenikmatan sesaat. Bentuk-bentuk tingkah laku ini bisa bermacam-macam mulai dari perasaan tertarik sampai tingkat laku berkencan, bercumbu dan bersenggama (Sarwono, 2011:114)

Menurut Wajiman (2015:23) remaja dan dorongan seksual adalah dua hal yang sangat berhubungan erat sehingga tidak bisa dipisahkan. Hal itu disebabkan pada fase remaja, mereka umumnya memiliki dorongan seksual yang sangat kuat, sedangkan resiko akibat kegiatan seksual yang menjurus pada hubungan seks belum sepenuhnya mereka ketahui. Penyebab dari keinginan berperilaku seks bebas ini yaitu faktor internal dan eksternal. Contoh akibat dari seks bebas untuk perempuan dibawah 17 tahun yang pernah melakukan 
hubungan seks bebas akan beresiko tinggi terkena kanker serviks. Beresiko tertular penyakit kelamin dan HIV-AIDS yang bisa menyebabkan kemandulan bahkan kematian. Terjadinya KTD (Kehamilan yang Tidak Diinginkan) hingga tindakan aborsi yang dapat menyebabkan gangguan kesuburan, kanker rahim, cacat permanen bahkan berujung kematian.

Terpantau bahwa seks bebas ini sudah masuk ke berbagai daerah, tak terkecuali Bengkulu. Untuk melakukan pencegahan agar tidak terjadi lebih banyak lagi kasus seks bebas, maka peneliti bermaksud memberikan sebuah layanan di salah satu sekolah di SMPN 3 Kota Bengkulu, khususnya di kelas VIII. Upaya penanggulangan yang bisa dilakukan SMP N 3 Kota Bengkulu adalah dengan menggunakan layanan informasi dengan materi bahaya seks pra nikah dan dari hasil layanan informasi yang telah diberikan saat ini dirasa kurang efektif untuk mengatasi permasalahan siswa ini. Maka untuk mengatasi permasalahan tersebut siswa yang mempunyai pemahaman rendah tentang bahaya akibatperilaku seks bebas yang tinggi dapat diberikan alternatif bantuan dalam menyelesaikan permasalahan yang sedang dialami melalui konseling dengan media Teknologi Informasi dan komunikasi.

Menurut Prayitno (2004:2) layanan informasi adalah kegiatan memberikan pemahaman kepada individu-individu yang berkepentingan tentang berbagai hal yang diperlukan untuk menjalani suatu tugas atau kegiatan, atau untuk menentukan arah suatu tujuan atau rencana yang dikehendaki. Dengan menggunakan layanan informasi dengan metode TIK, diharapkan dapat memberikan pemahaman lebih kepada remaja tentang apa itu seks secara utuh dan menghindari akibat-akibat yang ditimbulkan jika melakukan seks bebas.

Berdasarkan hal-hal diatas, tujuan yang ingin dicapai dari penelitian yang akan dilakukan ini adalah untuk mengetahui bagaimana "Pengaruh Layanan Informasi Dengan Media Teknologi Informasi Dan Komunikasi (TIK) Terhadap Pemahaman Siswa Tentang Dampak Perilaku Seks Bebas Pada Siswa Kelas VIII 4 Di Smp Negeri 3 Kota Bengkulu”

\section{Metode Penelitian}

Desain penelitian adalah semua proses yang diperlukan dalam perencanaan dan pelaksanaan penelitian Desain penelitian yang digunakan peneliti adalah desain penelitian eksperimen dengan jenis one group pretest-posttest design. Dalam penelitian ini dilakukan dengan dua kali pengukuran.Pengukuran pertama dilakukan sebelum kegiatan pemberian layanan informasi. Pengukuran kedua dilakukan setelah pemberian layanan informasi. Pendekatan yang digunakan yaitu dengan pendekatan eksperimen (Sugiyono, 2007: 110).

Teknik pengambilan sampel pada penelitian ini yaitu dengan menggunakan purposivesampling. Teknik purposivesampling adalah teknik pengambilan sampel dengan 
tidak berdasarkan random, daerah, strata, melainkan berdasarkan atas adanya pertimbangan yang berfokus pada tujuan tertentu (Arikunto: 2006). Teknik ini biasanya dilakukan karena beberapa pertimbangan, misalnya adanya keterbatasan waktu, tenaga, dan dana sehingga tidak dapat mengambil sampel yang besar dan jauh. Dalam penelitian ini peneliti bisa menentukan sampel berdasarkan tujuan tertentu, dan ada syarat-syarat yang harus dipenuhi, yaitu, Pertama, pengambilan sampel harus didasarkan atas ciri-ciri, sifat atau karekter tertentu, yang merupakan ciri-ciri pokok populasi. Kedua, subjek yang diambil sebagai sampel benar-benar merupakan subjek yang paling banyak (dominan) mengandung ciri-ciri yang terdapat pada populasi.

Teknik pengumpulan data dalam penelitian ini metode pengumpulan data yang digunakan adalah angket pemahaman bahaya akibat perilaku seks bebas. Alternatifjawabandari angket pemahaman bahaya akibat perilaku seks bebasterdiridari beberapapernyataanyang telah disediakan,yaitu:(Benar atau Salah ). Skorjawabanuntukitembergerakdarinilai 1 untuk jawaban Benar (B)dan 0 untuk jawaban Salah (S).

Pengujian validitas kuesioner pemahaman bahaya perilaku seks bebas dilakukan berdasarkan dengan penilaian dari para ahli. Rumusan yang dipakai adalah Gregory yang meminta pendapat dari 2 ahli dan jika didapatkan hasil jika Content validity >0,70 maka instrumen dapat dilanjutkan. Setelah dilakukan penilaian dari kedua ahli didapatkan nilai CV 0,89 yang berarti instrumen dapat dilanjutkan.

Uji reliabilitas kuesioner dilakukan untuk mengetahui bahwa angket dapat dipercaya. Hasil uji reliabilitas nilai Chonbach's Alpha sebesar 0,812 berarti angket tersebut sudah memiliki reliabilitas yang baik. Sesuai dengan yang dikatakan Setiawan (2015:140), interpretasi nilai koefisiensi reliabilitas dengan rentang nilai 0,8-1,00 memiliki interprestasi reliabilitas sangat tinggi. Data yang didapatkan kemudian diinterprestasikan dengan menggunakan analisis uji normalitas dan uji hipotesis uji-t.

\section{Hasil dan Pembahasan}

Deskripsi data pada bagian ini adalah tentang gambaran bagaimana pengaruh layanan informasi dengan menggunakan media TIK dalam meningkatkan pemahaman siswa tentang bahaya seks bebas. Hal ini dilakukan dengan memberikan beberapa kali layanan informasi dengan berbagai materi tentang seks bebas. Pemberian layanan ini dilakukan sebanyak 5 kali kepada 31 siswa di kelas VIII 4. Hasil yang didapat, diantaranya berupa hasil pre test dan post test untuk mengetahui seberapa berpengaruh layangan informasi dengan media TIK 
untuk meningkatkan pemahaman siswa tentang bahaya seks bebas. Berikut akan ditampilkan tabel pretest:

Tabel 1

Deskripsi Data Sebelum Diberikan Layanan Informasi

\begin{tabular}{ccccc}
\hline No & Kategori & Rentang Skor & N & F \\
\hline 1 & Tinggi & $>27$ & 7 & $23 \%$ \\
\hline 2 & Sedang & $14-26$ & 24 & $77 \%$ \\
\hline 3 & Rendah & $<13$ & - & - \\
\hline & Jumlah & & 31 & $100 \%$ \\
\hline
\end{tabular}

Berdasarkan data Tabel 1. Deskripsi data sebelum diberikan layanan informasi, diperoleh 7 orang siswa dengan presentase $23 \%$ yang memiliki pemahaman terhadap dampak perilaku seks bebas dengan kategori tinggi, sedangkan 24 orang siswa dengan presentase 77\%. Secara keseluruhan sebanyak 31 orang siswa memiliki hasil Pre-test sedang. Untuk leboh jelasnya, akan ditampilkan diagram gambar.

\section{Gambar 1}

Diagram Pretest Pemahaman Akibat Perilaku Seks Bebas

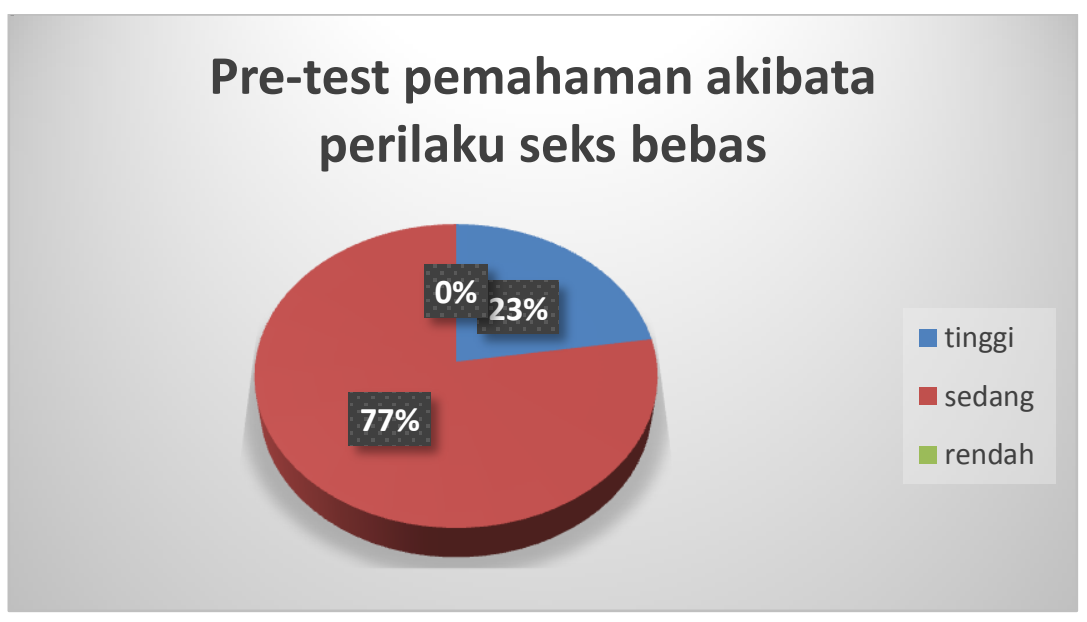

Berdasarkan gambar 1. diagram pretest pemahaman akibat perilaku seks bebas, dapat disimpulkan bahwa sebelum diberikan layanan informasi tentang pemahaman akibat bahaya perilaku seks bebas yang diperoleh dari angket tersebut siswa yang mendapatkan nilai dengan kategori tinggi sebanyak 7 orang siswa dengan presentase $23 \%$, kemudia siswa yang mendapat kategori sedang sebanyak 24 orang siswa dengan presentase 77\%. Dapat disimpulkan bahwa pemahaman siswa tentang akibat bahaya perilaku seks bebas pada siswa kelas VIII 4 dengan sampel sebanyak 31 siswa termasuk dalam kategori sedang. Oleh sebab 
itu peneliti perlu memberikan layanan informasi untuk meningkatkan pemahaman siswa tentang akibat bahaya perilaku seks bebas sebanyak 5 kali pertemuan

Setelah didapatkan data pretest, selanjutnya adalah mengetahui hasil yang didapatkan dari post test. Berikut akan ditampilkan tabel post test pemberian layanan informasi dengan media TIK dalam mengingkatkan pemahaman siswa tantang bahaya seks bebas.

Tabel 2

Deskripsi Data Setelah Diberikan Layanan Informasi

\begin{tabular}{lllll}
\hline No & Kategori & Rentang Skor & N & F \\
\hline 1 & Tinggi & $>27$ & 31 & $100 \%$ \\
\hline 2 & Sedang & $14-26$ & 0 & $0 \%$ \\
\hline 3 & Rendah & $<13$ & 0 & $0 \%$ \\
\hline & Jumlah & & 31 & $100 \%$
\end{tabular}

Berdasarkan data di tabel 2. Deskripsi data setelah diberikan layangan informasi, diperoleh bahwa semua siswa yang memiliki pemahaman terhadap akibat bahaya perilaku seks bebas dengan kategori tinggi dengan presentase 100\%. Secara keseluruhan sebanyak 31 orang siswa memiliki hasil Pos-test tinggi.

Gambar 2

Kategori Post-test

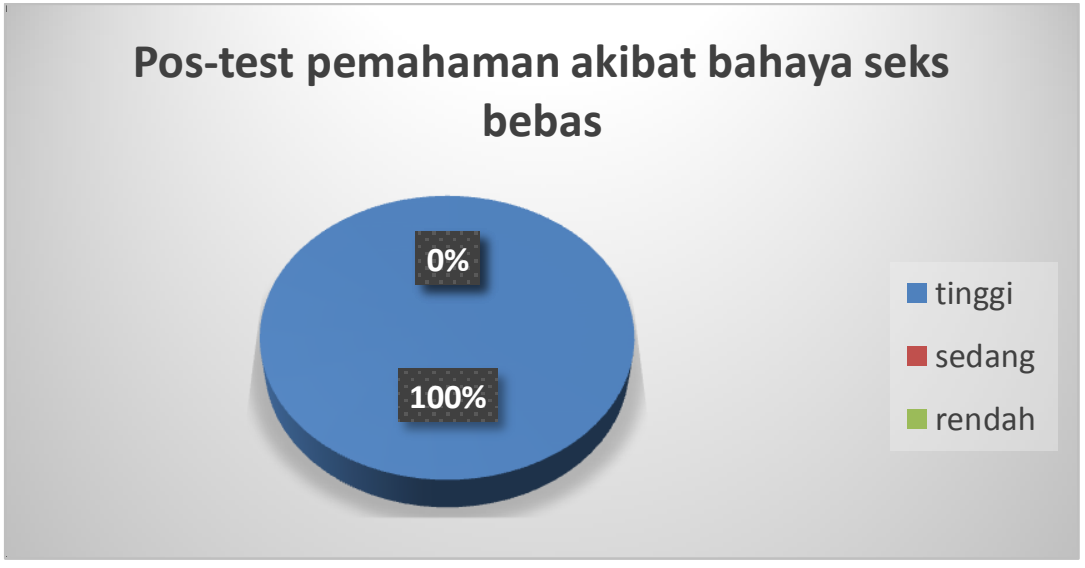

Berdasarkan tabel 2. Kategori post-test diperoleh bahwa semua siswa yang memiliki pemahaman terhadap akibat bahaya perilaku seks bebas dengan kategori tinggi dengan presentase $100 \%$. Dengan total seluruh siswa sebanyak 31 orang.Dari perbandingan pre-test dan post-test yang sudah ditampilkan, dapat diketahui bahwa ada peningkatan dari sebelum diberikan layanan informasi dan setelah diberikan layanan informasi.

Sebelum menguji hipotesis, terlebih dahulu dilakukan uji prasyarat analisis dengan menggunakan uji normalitas. Uji normalitas yang digunakan melihat nilai Shapiro-Walk 
dikarenakan jumlah subjek kurang dari 50. Dasar pengambilan keputusan dalam uji normalitas adalah jika nilai Sig. >0.05 maka dapat disimpulkan bahwa sampel berdistribusi normal. Sebaliknya jika nila Sig. <0,05 maka data tidak berdistribusi normal. Hasil uji normalitas menggunakan SPSS menunjukkan hasil bahwa bahwa nilai sig Shapiro-Wilk adalah lebih besar dari Sig. 0,05. Maka hasil uji normalitas dapat disimpulkan bahwa sampel pada penelitian ini berdistribusi normal.

Setelah melakukan uji normalitas, hal selanjutnya yang dilakukan adalah melakukan uji hipotesis dengan uji t. Berdasarkan hasil olah SPSS, hasil yang terdapat ialah, nilai t = 23,826 dengan Sig. (2- tailed) adalah 0,000 ( $<<0,05)$. Berdasarkan kategori penerimaan atau penolakan hipotesis itu berarti $\mathrm{H} 0$ ditolak dan Ha diterima, dengan demikian dapat disimpulkan bahwa terdapat pengaruh antara layanan informasi dengan media Teknologi Informasi dan Komunikasi (TIK) terhadap pemahaman siswa tentang akibat bahaya seks bebas pada siswa kelas VIII 4 SMP Negeri 3 Kota Bengkulu.

\section{Pembahasan}

Berdasarkan hasil penelitian diketahui bahwa terdapat peningkatan pemahaman tentang akibat bahaya perilaku seks bebas setelah diberikan layanan informasi. Dari 31 orang siswa yang ada di kelas VIII 4 yang memiliki pemahaman akibat bahaya perilaku seks bebas yang sedang. Hal ini ditandai dengan skor Pretest yang termasuk kategori sedang. Pemahaman tentang akibat bahaya perilaku seks bebas sudah seharusnya diberikan kepada remaja yang masuk pada masa dewasa. Seperti yang telah disebutkan pada suatu penelitian bahwa remaja membutuhkan informasi tentang pemahaman akibat bahaya perilaku seks bebas. Pada penelitian ini, siswa yang memiliki pemahaman dengan kategori sedang diberikan layanan informasi tentang pemahaman akibat bahaya perilaku seks bebas selama beberapa kali tatap muka. Pemberian layanan informasi bertujuan untuk memberikan pemahaman dan meningkatkan pengetahuan tentang bahaya akibata perilak seks bebas serta sikap tegas untuk menolak adanya perilaku seks bebas pada peserta didik.

Hasil Postest menunjukan terdapat peningkatan skor dari Pretest yang sedang menjadi meningkat pada Postest. Hal ini menunjukan bahwa setelah siswa diberikan layanan informasi siswa mengalami peningkatan pemahaman tentang bahaya akibat perilaku seks bebas. Selain itu dilakukan uji hipotesis menggunakan Uji t-test menunjukan nilai $\mathrm{t}=$ 23,826 . Hal ini menunjukan bahwa layana informasi dapat meningkatkan pemahaman tentang akibat bahaya perilaku seks bebas. Hasil signifikansi $0,000<0,05$ ini juga menunjukan kriteria penerimaan atau penolakan bahwa hipotesis Ho ditolak dan Ha diterima maka 
diperoleh hasil bahwa ada pengaruh layanan informasi dengan media TIK terhadap pemahaman siswa tentang akibat bahaya perilaku seks bebas. Dengan demikian terdapat perubahan tentang pemahaman akibat bahaya seks bebas siswa, yang semula dalam kategori sedang menjadi kategori tinggi setelah diberikan layanan.

Pemberian layanan informasi pada hasil penelitian ini sesuai dengan tujuan layanan informasi menurut Tohirin (2007: 147) yang menyatakan layanan informasi bertujuan agar individu (siswa) mengetahui menguasai informasi yang selanjutnya dimanfaatkan untuk keperluan hidupnya sehari-hari dan perkembangan dirinya. Layanan informasi bertujuan untuk pengembangan kemandirian, dan penguasaan individu terhadap informasi yang diperlukannya akan memungkinkan individu : (a) mampu memahami dan menerima diri dan lingkungannya secara objektif, positif, dan dinamis, (b) mengambil keputusan, (c) mengarahkan diri untuk kegiatan-kegiatan yang berguna sesuai dengan keputusan yang diambil, dan (d) mengaktualisasikan secara terintegrasi

\section{Kesimpulan}

Berdasarkan hasil penelitian yang telah dilakukan, didapatkan bahwa adanya perubahan sikap dan pemahaman siswa sebelum dan setelah diberikan layanan informasi. Perubahan tersebut dapat dilihat juga dari hasil skor pre-test dan post-test siswa yang mengalami peningkatan pemahaman tentang bahaya akibat perilaku seks bebas. Uji hipotesis menggunakan Uji t-test menunjukan nilai $\mathrm{t}=-23,826$. Hal ini menunjukan bahwa layana informasi dapat meningkatkan pemahaman tentang akibat bahaya perilaku seks bebas. Hasil signifikansi $0,000<0,05$ ini juga menunjukan kriteria penerimaan atau penolakan bahwa hipotesis Ho ditolak dan Ha diterima, sehingga dapat disimpulkan bahwa "Ada Pengaruh Layanan Informasi Dengan Media Teknologi Informasi dan Komunikasi Terhadap Pemahaman Siswa Tentang Dampak Perilaku Seks Bebas Pada Siswa Kelas VIII 4 SMP Negeri 3 Kota Bengkulu.

\section{Daftar Pustaka}

Arikunto, S. 2006. Prosedur penelitian suatu pendekatan praktik. Edisi Revisi VI, Jakarta: Rineka Cipta

Dariyo. (2004). Psikologi perkembangan dewasa muda. Jakarta: Grasindo.

Prayitno. (2004). Kegiatan Pendukung Konseling (L1-L9).Padang: FIP UNP.

Sarwono, S.W. (2011). Psikologi Remaja. Edisi Revisi. Jakarta: Rajawali Pers.

Sarwono. (2011). Ilmu kandungan. Jakarta: bina Pustaka 
Setiawan. (2015). Metode Penelitian (Suatu Pendidikan Proposal). Jakarta: Bumi Aksara.

Sugiyono, (2007). Memahami Penelitian Kualitatif. Bandung: Alfabeta.

Tohirin. (2013). Bimbingan Dan Konseling Di Sekolah Dan Madrasa(Berbasis Integrasi) Edisi Revisi V. Jakarta: Rajawali Pers.

Wajiman. (2015). Remaja dan Berbagai Problematika. Jurnal Dimensi Pendidikan dan Pembelajaran 5(1).

Willis, S.S.,(2005). Remaja dan Masalahnya. Alfabeta, Bandung. 